\title{
Economic Feasibility Study on The Development of Irrigation Channels
}

\author{
Zakia $^{1 *}$, Meylis Safriani ${ }^{1}$, Nessa Radianica ${ }^{1}$, M. Faisi Ikhwali ${ }^{2}$ \\ ${ }^{1}$ Department of Civil Engineering, Universitas Teuku Umar, Aceh, Indonesia \\ ${ }^{4}$ Department of Environmental Engineering, Universitas Islam Negeri Ar-Raniry, Aceh, Indonesia \\ *Corresponding author E-mail: zakia@utu.ac.id
}

\begin{abstract}
Manuscript received 16 Nov 2021; revised 20 Nov 2021; accepted 1 Jan 2022. Date of publication 10 Jan 2022

Indonesia is an agricultural country where the livelihood of the majority of the population is farming. Geographically, Indonesia is an archipelagic country that has enormous natural potential, both in the marine and agricultural fields. The agricultural sector is a sector that has an important role in improving the welfare of the entire population of Indonesia. Rice fields in Blang Beurandang Village still rely on irrigation from using rainwater to meet irrigation water needs. To increase rice yields, an irrigation network is needed that can flow water to the rice fields. It is necessary to conduct a feasibility study on the irrigation to be built so that it can be calculated from an economic point of view whether the project is feasible or not. This feasibility study is equipped with an analysis using the first method; Net Present Value (NPV), the second is the Benefit Cost Ratio (BCR) analysis, the third is the Internal Rate of Return (IRR), and the fourth is the Break Event Point (BEP). The results of this study are the value of the investment cost of the construction project or the initial capital of the irrigation canal which is IDR. 2,088,058,500, and the value of the operational and maintenance costs is IDR. 9,578,250 per year. The results obtained that NPV was IDR. 30,614,330, BCR was $1.01 \%$, IRR was $5.88 \%>5 \%$ and BEP occurred in the $22^{\text {nd }}$ year and the $7^{\text {th }}$ month. Based on the calculation results obtained from these four methods, it shows that the irrigation channel construction project has met the eligibility requirements and the project can be implemented or built. This means that the construction of irrigation networks in the village is feasible.
\end{abstract}

Keywords: Economic, Feasibility Study, Irrigation Networks, BEP.

\section{Introduction}

The agricultural sector is a sector that has an important role in efforts to improve the welfare of the whole community. Conceptually, the construction of irrigation canals aims to support national food supply, so that the availability of water in the land will be fulfilled even though the land is far from surface water sources. This cannot be separated from the irrigation technique, namely providing water with the appropriate quality conditions, in the right space and at the right time in an effective and economical way.

Blang Beurandang Village, Johan Pahlawan District, West Aceh Regency has an area of about 500 ha of rice fields. The condition of the people in the village is the majority of their livelihood as farmers. Irrigation in rice fields still relies on rainwater. This has an impact on crop yields where in a year the harvest is only done twice times with harvesting periods in May and September. To avoid rice fields do not experience a water crisis during the dry season, irrigation projects are needed. Firstly, A project that will run or be developed needs an economic feasibility study to determine whether the investment in the project is successful or not. This study analyzes the economic feasibility study on the Construction of Irrigation Channels in Blang Beurandang Village, Johan Pahlawan District, West Aceh Regency to review whether it is included in the feasible criteria or not.

The importance of a feasibility study is to assess the feasibility of investing in a project. According to Kasmir and Jakfar [1], a feasibility study is an activity that studies in depth about the activities to be carried out in order to determine whether the project is feasible or not, one of which is avoiding the risk of loss. This feasibility study is complemented by the first analysis, namely Net Present Value (NPV), which aims to calculate the current net income. The second is the Benefit Cost Ratio (BCR) analysis which aims to emphasize the value of the comparison between the benefits to be obtained with aspects of costs and losses that will be costs with the investment. The third is the Internal Rate of Return (IRR) which aims to get the results of NPV $=0$. The fourth is the Break Event Point (BEP) which aims to increase or balance the costs incurred and those obtained.

Previously researches on the economic feasibility study of water resources projects has been carried out by several researchers, including the research "Economic Feasibility Analysis of the Keuruto Reservoir Development in North Aceh Regency, Aceh Province"[2]. Trikomara and Fauzi explained that the Net Present Value (NPV) was IDR. 131,894,993,000,- or NPV > 0, Internal Rate of Return (IRR) of 11.50\% or IRR $>10 \%$, Break Event Point (BEP) occurs in the 27 th year and the 7 th month. From these acquisitions, it is concluded that this project is feasible because it meets the criteria in the feasibility study and the payback period is smaller than the economic life of the project, which is 50 years. 
Several construction projects, apart from irrigation canals, have also carried out a feasibility analysis. In the construction of the PLTM, the payback time or BEP (Break Even Point) was obtained for 6.56 years [3]. The BEP of a project depends on the type of project, the cost of income and expenses. For the Gintung Dam, which functions as a flood control, the break-even point is 27 years with longer payback time. This is much cost during construction so that the BEP is also longer [4]. In highway projects, an economic feasibility evaluation will be carried out if the proposed development is credible and useful. Recommended BEP should not be too long. For road projects with a 20year BEP value, it is necessary to reconsider the implementation of its construction [5]. In the bridge project, a feasibility study is carried out in more detail with several alternative road paths proposed. Alternative bridge paths are made as effective and efficient as possible because they are safer from river scouring hazards [6].

Another research related to the economic feasibility analysis of the project, namely "Financial Evaluation Study of Irrigation Network Maintenance Projects" [7]. Suharto [7] concluded that there was an increase in production after the irrigation project was built by 5.7\%. The IRR value obtained is $12 \%$ and the NPV is IDR. 2,041,687,650.31. The project's financial evaluation shows that the project is feasible. The BEP period for irrigation buildings is 5 years 6 months 11 days. The depreciation value for this project is IDR 420,000,- for 25 years, with a final value of IDR 4,500,000.

Based on several related studies regarding project feasibility analysis [8]-[14], this study will purpose to do economic feasibility study on the other spesific object involved in the development of irrigation channels. The first aim is to determine the results of an economic study on Irrigation Canal Development in Blang Beurandang Village, Johan Pahlawan District, West Aceh Regency with the Net Present Value (NPV), Benefit Cost Ratio (BCR), Internal Rate of Return IRR, and Break Event Point (BEP) methods. The second aim is to determine the feasibility criteria on the results of the economic feasibility study on the Construction of Irrigation Channels in Blang Beurandang Village, Johan Pahlawan District, West Aceh Regency.

\section{Literature Review}

The purpose of the feasibility study is to analyze the amount of investment spent on development whether it will provide benefits for investors and the government or not [15]. A business feasibility study is a decision-making tool needed to assess and decide whether a business activity/project is feasible or not to be carried out [16]. An investment is said to be feasible if it meets the following criteria: (1) NPV is greater than zero, (2) IRR is greater than the current discount rate, (3) BCR is greater than 1 [17]. In addition to NPV, BEP and IRR, there are various methods for evaluating investment feasibility, namely the Annual Equivalent (AE) Method and the Payback Period (PBP) Method) [18]. To be able to analyze the feasibility of a project, data are needed such as components of pre-construction costs (planning and land acquisition), construction costs and maintenance operating costs [19].

The project feasibility analysis follows the "discounted cash flow" methodology or in other words calculates the growth prospects of an investment in the future. The economic feasibility of the project is determined by the value of NPV, BCR, IRR, and BEP and takes into account the interest rate set. The Net Present Value (NPV) method is a method of calculating the net value (net) at the present time. The present assumption is to explain that the initial time of the calculation coincides with the time the evaluation is carried out or in the 0 year period in the calculation of investment cash flow [14]. The formula used to calculate the NPV value is [20]:

$\mathrm{NPV}=\mathrm{PWB}-\mathrm{PWC}$

Where :

PWB = Present Worth of Benefit;

PWC = Present Worth of Cost;

Formula to calculate PWB and PWC [11].

$$
\begin{aligned}
& P W B=\sum_{t-0}^{n} C B t(F E B) t \\
& P W C=\sum_{t-0}^{n} \operatorname{CCt}(F E B) t
\end{aligned}
$$

Where:

$$
\begin{array}{ll}
\mathrm{Cb} & =\text { Cash flow benefit; } \\
\mathrm{Cc} & =\text { Cash flow cost; } \\
\mathrm{FBP} & =\text { Present Interest Factor; } \\
\mathrm{n} & =\text { Investment period; } \\
\mathrm{t} & =\text { Time period; }
\end{array}
$$

The results of the NPV calculation on the investment decisions to be made are :

$$
\begin{array}{ll}
\text { - If } \quad: \quad & \text { NPV is positive, then the investment is feasible; } \\
& \text { NPV is negative, then the investment is not feasible. } \\
\text { - If } \quad: \quad & \text { NPV }>0 \text {, then the investment is feasible; } \\
& \\
&
\end{array}
$$

Aspects of benefits and costs in government projects have a broader meaning than usual, where these aspects are often found in indirect form. For example, investing in the opening of new roads will not only make travel times shorter or more efficient, but will also result in other benefits such as increasing land productivity around the community's economic growth road, and so on. In addition to benefits, there are other costs that must be incurred by the community in the form of negative impacts such as costs for the impact of environmental changes, decreased levels of security and comfort, instruction of socio-cultural values, and so on due to the opening of new roads. 
In general, BCR analysis method uses the following formula [20].

$B C R=\frac{P W B}{P W C}$

Where:

$P W B=\sum_{t=0}^{n} C B t(F B P) t$

$P W B=C b(1+i)$

$P W B=\sum_{t=0}^{n} \operatorname{Cct}(F B P) t$

$P W C=C c(1+i)$

Where:

PWB = Present Worth of Benefit;

PWC = Present Worth of Cost;

$\mathrm{Cb} \quad=$ Cash flow benefit;

$\mathrm{Cc} \quad=$ Cash flow cost;

FBP = Present interest factor;

$\mathrm{n} \quad=$ investment period;

$\mathrm{t}=$ time period.

The criteria to determine whether an investment plan is economically feasible or not using the BCR method are:

- If $\mathrm{BCR}>1 \rightarrow$ feasible investment;

- If $\mathrm{BCR}<1 \rightarrow$ investment is not feasible (Unfeasible)

Internal Rate of Return (IRR) is an interest rate (not bank interest) that describes the level of profit from a project or investment in percentage when the NPV value is equal to zero [20]. IRR is the interest rate that illustrates that the benefits presented are equal to zero [20].

The formula used to calculate the IRR is [20].

$I R R=i N P V 0+\frac{N P V O}{(N P V O+N P V 1)}(i N P V O-i N P V 1)$

Where:

iNPV0 $=$ interest rate net present value at $i_{0}$;

iNPV1 = interest rate net present value at I;

NPV0 = net present value at $\mathrm{i}_{0}$;

$\mathrm{NPV}=$ net present value at $\mathrm{i}$

The criteria to assess the feasibility of a business or project in terms of the Internal Rate of Return are as follows [21] :

- $\quad$ If IRR > rate of return, then the investment is feasible;

- $\quad$ If $I R R \leq$ rate of return, then the investment is not feasible to execute.

Break Even Point (BEP) is the payback period or the break-even point where the expenditure and income are balanced $(\mathrm{NPV}=0)$ so that at that time the investment do not experience a loss or profit. This method uses a trial and error technique of time/period until the cost of income $=$ the cost of expenditure [22]. The formulation for BEP is [22].

$\frac{n 1-n x}{N P n_{1}-0}=\frac{n 1-n 0}{N P V n_{1}-N P V n_{-} 0}$

Where:

$\mathrm{nx}=$ required year value $(\mathrm{BEP})$;

$\mathrm{n} 0=$ year at $\mathrm{t} 0$;

$\mathrm{n} 1=$ year at $\mathrm{t} 1$;

NPVn_0 = net present value at $\mathrm{t} 0$;

$\mathrm{NPVn} \mathrm{n}_{1} 1=$ net present value at $\mathrm{t} 1$. 


\section{Methods}

This section will describe the research methods that was used in the economic feasibility study on the construction of irrigation channels in Blang Beurandang Village, Johan Pahlawan District, West Aceh Regency. The methodology used in this research collected data, literature studies, and developing assumptions and cash flow analysis. The flow chart of this research can be seen in the following flowchart (Figure 1).

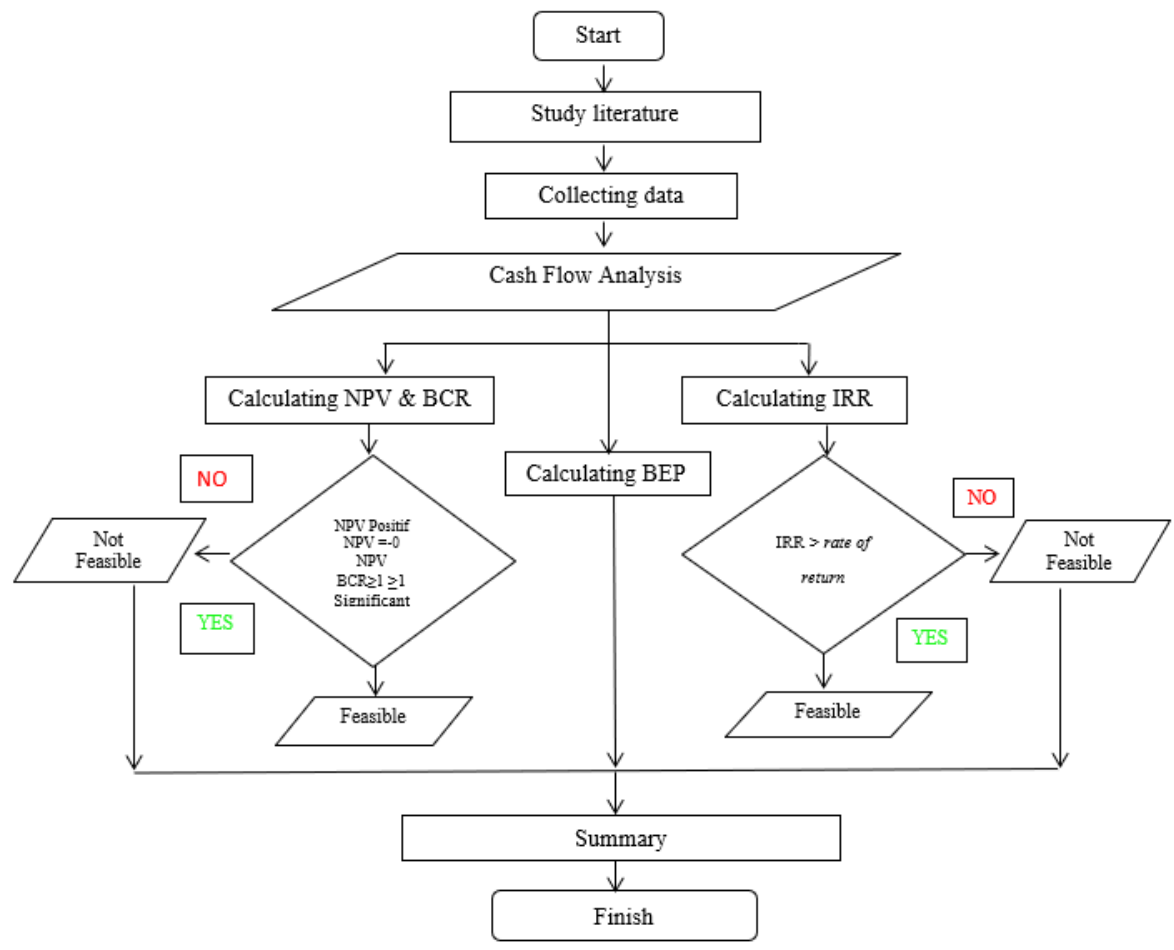

Fig 1. Flowchart of Methodology

\subsection{Method of collecting data}

The data needed in the Economic Feasibility Study on the Construction of Irrigation Channels in Blang Beurandang Village, Johan Pahlawan District, West Aceh Regency in the form of primary data, secondary data, and assumptions related to the calculation of data analysis. The data was obtained from various literatures that support research, data obtained from agencies or other agencies related to this research. Secondary data in this study are in the form of image data, the results of the calculation of the Budget Plan, and maps related to the location of the project being studied.

\subsection{Primary data}

The primary data in this study is data on the benefits of irrigation canals obtained from interview studies with several village officials such as head of village, village secretary, ulee balang and the community as many as two respondents. The method in project evaluation in this development uses a comparison method between conditions before the project and after the project. Data collection was conducted by surveys and interviews.

\subsection{Secondary data}

The secondary data in this study are in the form of image data, the results of the calculation of the Budget Plan, and maps related to the location of the project being studied.

\subsection{Study Area}

This research is located in Blang Beurandang Village (Figure 2), which is one of the villages of Johan Pahlawan Subdistrict, West Aceh Regency. Administratively, Blang Beurandang Village is directly adjacent to 4 villages, namely: in the north with Kawai XVI District, in the south with Pasi Mesjid Village, in the east with Ranub Dong Village and in the west with Leuhan Village. Geographically, Blang Beurandang Village is located at 04013’28,35” North Latitude (LU) and 9607’34,29” South Latitude (LS). 


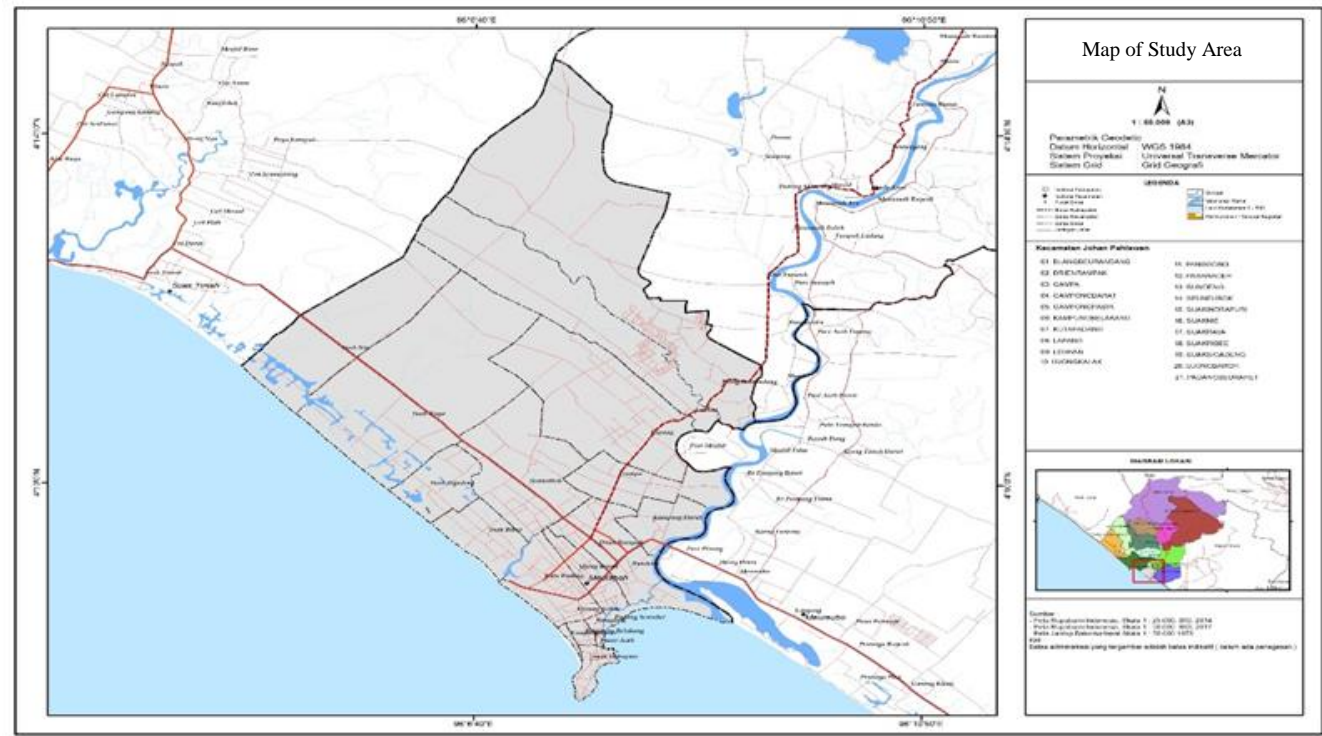

Fig 2. Study Area

\subsection{Assumption}

Assumptions are estimation that will be used in the research. In the construction of irrigation canals the assumptions used include several points, including: (1) The economic life or the service life of the irrigation canal building in this project is 50 years with a maintenance period of 25 years; (2) The interest rate is based on Bank Indonesia standards.

Based on the results of the Board of Governors Meeting of Bank Indonesia No.21/52/DKom on 17-18 July 2019 decided to set an interest rate of 5\%. When some data is collected, assumptions are made to get an estimate or estimate that will be used in the study. The following are the steps of analysis in this research.

\subsection{Budget Plan}

This study uses a Budget Plan obtained from the Department of Public Works and Irrigation as initial data (investment) for calculation in cash flow analysis. This calculation includes the cost of capital consists of direct costs and indirect costs. Direct costs include land acquisition costs and construction costs. While the indirect costs include the cost of consulting services and take $4 \%$ fee from direct cost and the cost of the possibility/unexpected things used from $5 \%$ of the direct cost (source: standard cost for project planning).

a. Cash Flow

After all the data and assumptions needed are collected, then input data for data analysis is carried out by making cash flow. Based on the cash flow, the infromation data processed used to solve the problem formulation in the research.

b. Net Present Value Analysis (NPV)

The NPV calculation result obtained using the formula in Equation 1. If the NPV is positive, NPV $>0$, and the NPV has a significant value from the initial capital, then the investment activity declared as feasible to carry out.

c. Benefit Cost Ratio Analysis (BCR)

The BCR calculation obtained the results using the formula in Equation 4. If the BCR value is $\geq 1$, then the investment activity can be declared feasible to be carried out. However, if not, then the investment activity is declared unfeasible.

d. Internal Rate of Return Analysis (IRR)

The results of the IRR calculation are obtained using the formula in Equation 7. If the IRR value is $\geq$ the interest rate, then the investment activity can be declared feasible to be carried out. However, if not, then the activity is declared not feasible.

e. Break Even Point Analysis (BEP)

$\mathrm{BEP}$ is obtained from the formula in Equation 8. Then from the calculation results, interpolation will be carried out to get the BEP results when NPV $=0$.

\section{Results and Discussion}

The feasibility study of this project greatly influences future planning. The planning is related to the calculation of the planned cash flow analysis to see the profits and losses obtained. The results of the Economic Feasibility Study on the Construction of Irrigation Channels in Blang Beurandang Village, Johan Pahlawan District, West Aceh Regency are said to be feasible if the NPV value $>0$, BCR > 1, IRR > rate of return, and BEP occurs before the planned economic life of the project is 30 year.

\subsection{Budget Plan}

The irrigation channel in Blang Beurandang Village will be built with a length of $1000 \mathrm{~m}$. Construction of irrigation networks requires costs. These costs lead to expenditures before the occurrence of the project which includes direct costs, indirect costs and annual costs.

a. Direct costs

Direct costs are costs required for the construction of a project, such as the Budget Plan. This cost shows the details of the work items to be carried out, from preparation to finishing. In the construction of this irrigation canal, the Budget Plan was obtained from the Department of Public Works and Irrigation. Direct cost is the entire work item, starting from preparatory work to construction of 
channel. Direct costs are part of the initial capital costs incurred. The total of the Budget Plan after adding 10\% VAT is IDR $1,915,650,000$

\section{b. Indirect Cost}

Indirect costs are costs associated with the overall project development process. Indirect costs include components consisting of consulting service fees and contingency costs. These costs occur only during the project development process. It is known that obtaining these indirect costs requires an interest rate. In the construction of the irrigation network, the total indirect costs are IDR. 172,408,500.

c. Annual Fee

Annual costs are costs that must be incurred during the life of the project. As long as the use of the project still requires costs until the project is completed and is a burden that still has to be covered by the investor. The calculated annual costs are operational costs and maintenance costs. The operational and maintenance costs for the construction of the irrigation network are IDR 9,578,250.

d. Cash Flow Analysis

Expenses are very certain to occur in a project that is being built. The costs incurred must be in accordance with the conditions that occur in the field. The total cost of expenditure or cash flow costs, calculated by adding up direct costs, indirect costs and annual costs. This total cost is the cash flow cost used for the calculation of cash flow analysis. Then the total cost of expenses is:

Total costs = direct costs + indirect costs + annual costs

$=$ IDR 1.915.650.000 + IDR 172.408.500 + IDR 9.578.250

$=$ IDR 2.097.636.750

e. $\quad$ Net Present Value Analysis (NPV)

The Net Present Value (NPV) method is a method of calculating the difference in the net value (net) at the present time of incoming cash flows with the present value of cash flows out of a certain period. When calculating the NPV the value of PWB and PWC must be known first. PWB (Present Worth Benefit) which has the meaning of calculating the value of profits while PWC (Present Worth Cost) which means calculating the value of losses/expenditures. In calculating the NPV, data is needed about the estimated investment costs, operational and maintenance costs and the estimated benefits of the planned project. The NPV value obtained is positive, which is IDR 30,614,330. This value meets the eligibility requirements of a project, namely NPV $>0$;

$\mathrm{NPV}=\mathrm{PWB}-\mathrm{PWC}$

$\mathrm{NPV}=(\mathrm{Cb}(1+\mathrm{i}) \mathrm{n})-(\mathrm{Cc}(1+\mathrm{i}) \mathrm{n})$

NPV $=((704.700 .000(1+5 \%) 23)+(22.344 .000(1+5 \%) 23))-((2.088 .058 .500(1+5 \%) 1)+(9.578 .250(1+5 \%) 1))$

$\mathrm{NPV}=2.233 .132 .918-2.202 .518 .588$

$\mathrm{NPV}=30.614 .330>0($ FEASIBLE $)$

\section{f. Benefit Cost Ratio Analysis (BCR)}

Benefit Cost Ratio (BCR) method in application, a project is said to be feasible if the BCR amount is $>1$, whereas if a project is said to be unfit to run when it only gets the BCR $<1$. When calculating the BCR, the first step is to know the value of PWB and PWC. The PWB value is obtained from the calculation of the total project benefits with the interest rate and project year. While PWC is obtained from the calculation of the sum of project expenditures with interest rates and project years. If you look at the formula above, it means that the completion of the NPV method with the BCR method has similarities, only the difference lies in the division for the BCR formula and the subtraction for the NPV formula. The search for the BCR value for this project was found to be 1.01\%, meaning that the project is feasible to implement.

$\mathrm{BCR}=\mathrm{PWB} / \mathrm{PWC}$

$\mathrm{BCR}=(\mathrm{Cb}(1+\mathrm{i}) \mathrm{n}) /(\mathrm{Cc}(1+\mathrm{i}) \mathrm{n})$

$\mathrm{BCR}=((704.700 .000(1+5 \%) 23)+(22.344 .000(1+5 \%) 23)) /((2.088 .058 .500(1+5 \%) 1)+(9.578 .250(1+5 \%) 1))$

$\mathrm{BCR}=2.233 .132 .918 / 2.202 .518 .588$

$\mathrm{BCR}=1.01>1($ FEASIBLE $)$

g. Internal Rate of Return Analysis (IRR)

The Internal Rate of Return (IRR) method is a method that shows an interest rate (not bank interest) that describes the profit rate of a project or investment in percentage at the time where the NPV value is 0 . If the calculation result is the same as the interest rate, it is said that the investment invested will return on investment, while if the IRR is less than the interest rate, then the investment is not feasible. To calculate the IRR value, a comparison is made between the assumption of an interest rate of $4.80 \%$ and an interest rate of $5.10 \%$, from the assumption of an interest rate of 5\%. The IRR interest rate obtained is $5.88 \%$, which shows the IRR is greater than the interest rate (i) which is 5\%. This IRR value meets the requirements for the feasibility of a project, namely IRR > rate of return. For more details, see the following calculations:

If IRR with $\mathrm{i}=4,80 \%$

$\mathrm{NPV}=(\mathrm{Cb}(1+\mathrm{i}) \mathrm{n})-(\mathrm{CC}(1+\mathrm{i}) \mathrm{n})$

$\mathrm{NPV}=((704.700 .000(1+4.80 \%) 23)+(22.344 .000(1+4.80 \%) 23))-((2.088 .058 .500(1+4.80 \%) 1)+(9.578 .250(1+4.80 \%) 1))$

$\mathrm{NPV}=2.137 .323 .179-2.198 .323 .214$

$\mathrm{NPV}=-61.000 .135$

If IRR with $\mathrm{i}=5,10 \%$

$\mathrm{NPV}=(\mathrm{Cb}(1+\mathrm{i}) \mathrm{n})-(\mathrm{CC}(1+\mathrm{i}) \mathrm{n})$

$\mathrm{NPV}=((704.700 .000(1+5.10 \%) 23)+(22.344 .000(1+5.10 \%) 23))-((2.088 .058 .500(1+5.10 \%) 1)+(9.578 .250(1+5.10 \%) 1))$

$\mathrm{NPV}=2.282 .565 .051-2.204 .616 .224$

$\mathrm{NPV}=77.948 .827$

Then the IRR is calculated using Equation ;

IRR $=\mathrm{iNPV0}+\mathrm{NPV0} /((\mathrm{NPV} 0+\mathrm{NPV} 1)(\mathrm{NPV} 0-\mathrm{NPV} 1)$

IRR $=4,80 \%+(-61.000 .135) / 16.948 .692 \times(-0,30 \%)$

IRR $=5,88 \%>5 \% \quad$ (FEASIBLE)

h. Break Even Point (BEP) 
The BEP method is a method that takes into account the payback period or the break-even point where the costs incurred and income are balanced (NPV $=0)$, so that at that time the investment do not experience a loss or profit. In another sense, this "break-even point" usually compares the amount of income or the amount of expenditure on a project. BEP is obtained by using a time/period trial technique until the NPV value $=0$. The calculation of BEP is obtained from a comparison experiment, if the IRR formula uses a comparison of interest rates, another case with the BEP method uses a comparison of years. In determining the comparison using the NPV in the 23 rd year and the 24th year. From the results of the comparison, interpolation of the values is carried out to obtain the BEP. From the results of the completion of the formula, the BEP value obtained is the 22nd year of the 7th month, which means that the BEP occurs before the economic life of the project, which is 30 years. Then the BEP value meets the eligibility requirements of a project. NPV in the 23rd year

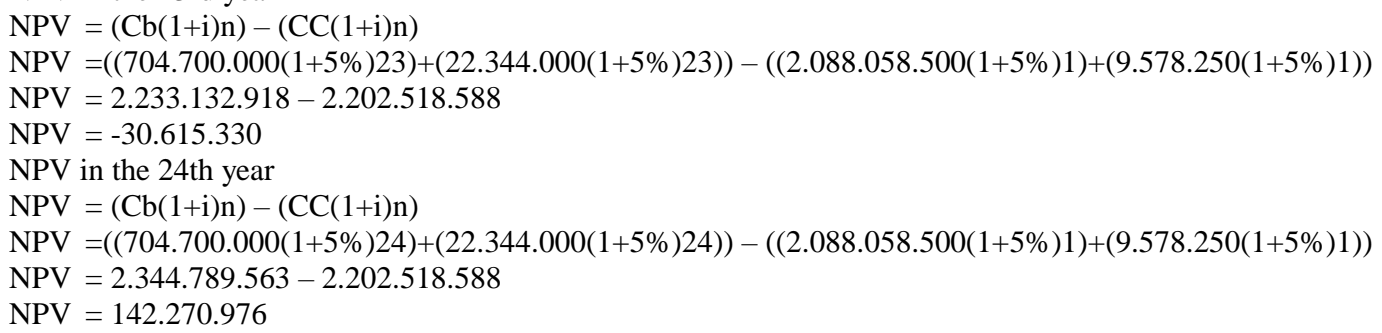

From the above calculations, interpolation is carried out to get the NPV $=0$ using Equation ;

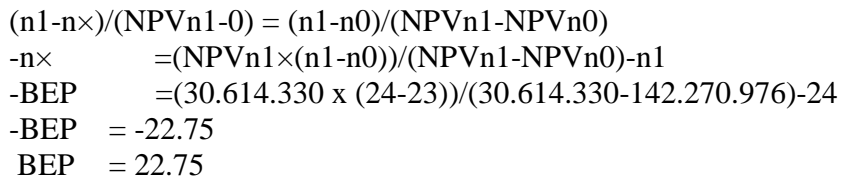

The BEP obtained is the 22nd year and the 7th month. The following shows the BEP chart.

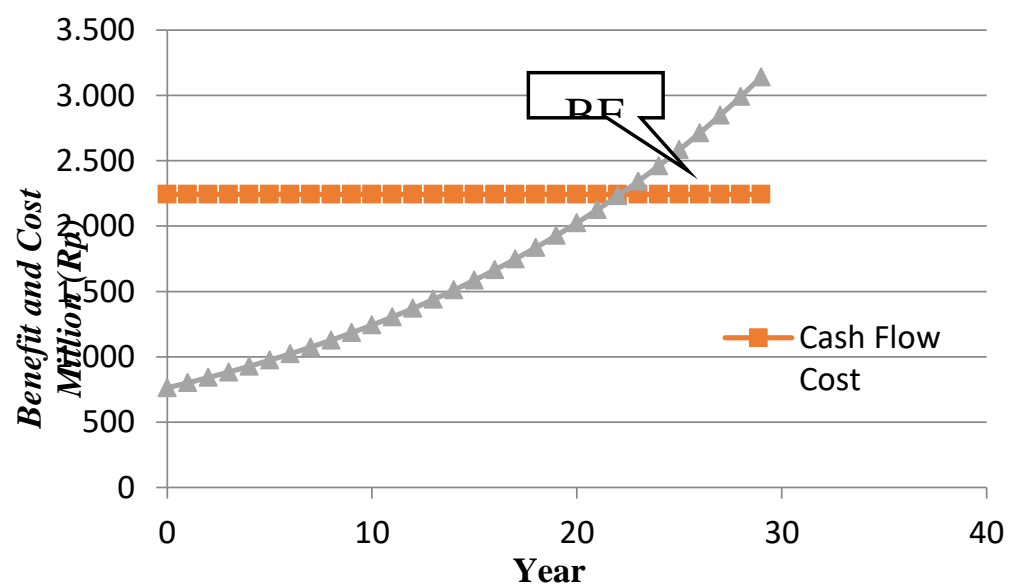

Fig 3. BEP of Cash Flow Benefit and Cash Flow Cost

The BEP graph in Figure 3 shows that in the 1st year, the benefit obtained was IDR 763. 396.200, by adding up the rice harvest and the selling price of the land. In the following year there is an increase in the graph, this is due to an increase in the year. In the following year, namely the 22nd year and the 7th month with a cash flow of IDR 2,233,132,917, a break-even point or payback period occurred which was marked by a meeting between the two graphs. It means that the BEP is balanced between expenditure and income $(\mathrm{NPV}=0)$ so that at that time the investment does not experience a loss or profit. For expenses or cash flow costs, the graph is only straight or parallel and does not increase or decrease because the results of cash flow costs are obtained from the sum of direct costs, indirect costs and annual costs. Direct costs only occur when the initial capital of the project is implemented, while the annual costs will be the same every year until the end of the life of the irrigation channel construction project.

\section{Conclusion}

The results of the cash flow analysis in the economic feasibility study on the construction of irrigation channels. dit can be concluded that the initial cost of the irrigation channel construction project in Blang Beurandang Village, Johan Pahlawan District, West Aceh Regency is IDR 2,088,058,500. The amount of benefits obtained from the construction of this irrigation canal is IDR 727,044,000. The results of cash flow analysis using the NPV method are IDR 30,614,330, the BCR method is IDR $1.01 \%$, the IRR method is IDR 5.88\%, and BEP occurs in the 22nd year and the 7th month. The results obtained from the Economic Feasibility Study on the Construction of Irrigation Channels in Blang Beurandang Village, Johan Pahlawan District, West Aceh Regency are feasible to be carried out on all analytical methods carried out, because at an interest rate of 5\% it shows a feasibility indicator, namely a positive NPV value, BCR $>1$, IRR $>5 \%$, and the BEP is less than the operational life of 30 years. The existence of this irrigation can increase the income of the community in Blang 
Beurandang Village, which initially the harvest process was only carried out 2 times a year but after the irrigation development the community's harvest process increased 3 times a year.

\section{Acknowledgement}

We acknowledge support from Water Resources Engineering of Universitas Teuku Umar and UIN Ar-araniry Banda Aceh, Indonesia.

\section{References}

[1] Kasmir and Jakfar, Studi Kelayakan Bisnis. Kencana Prenada Media, 2012.

[2] M. Tumer, "Analisis Kelayakan Ekonomi Pembangunan Waduk Keureuto Di Kabupaten Aceh Utara Provinsinangroe Aceh Darusalam," pp. 323-326, 2006.

[3] W. Sulistiono, "Tinjauan Manajemen Investasi Pada Proyek Pltm Siteba Iv Kabupaten Luwu," PENA Tek. J. Ilm. Ilmu-Ilmu Tek., vol. 1, no. 1, p. 39, 2016.

[4] A. U. Kalsum, D. Sutjiningsih, E. Anggraheni, and S. Murniningsih, "Economic feasibility analysis of Gintung Dam," IOP Conf. Ser. Earth Environ. Sci., vol. 599, no. 1, 2020.

[5] Pratiksha Patil, "Economic Feasibility Analysis of Highway Project.," Int. J. Eng. Res., vol. V9, no. 07, pp. 1042-1045, 2020.

[6] N. R. Setiati, "The feasibility study of bridge construction plan in Digoel River Province of Papua," IOP Conf. Ser. Earth Environ. Sci., vol. 235, no. 1, 2019.

[7] B. Suharto, R. Wirosoedarmo, and A. K. Abstrak, "Studi Evaluasi Finansial Pada Proyek Pemeliharaan Jaringan Irigasi," J. Teknol. Pertan., vol. 2, no. 1, pp. 78-86, 2021.

[8] H. Pristianto, "Studi Kelayakan Bendungan Remu Kota Sorong," vol. I, 2018.

[9] H. Y. Febriyan, D. R. O. Walangitan, and M. Sibi, "Studi Kelayakan Proyek Pembangunan Perumahan Bethsaida Bitung Oleh Pt. Cakrawala Indah Mandiri Dengan Kriteria Investasi,” J. Sipil Statik, vol. 5, no. 7, pp. 401-410, 2017.

[10] R. Rimawan and A. Prasetyo, "Analisis Kelayakan Bendung Cipasauran Sebagai Sumber Air Baku Bagi Pt Krakatau Tirta Industri," J. Tek. Hidraul., pp. 129-142, 2013.

[11] E. F. M. F. Ramadhani and Soepriyono, "Studi kelayakan proyek pembangunan perumahan graha natura di surabaya," J. Rekayasa dan Manaj. Konstr., vol. 7, no. 1, pp. 53-66, 2019.

[12] K. Nuraga and I. G. L. B. Eratodi, "Feasibility Study Bendungan Poh Santen Di Kabupaten Jembrana," INERSIA INformasi dan Ekspose Has. Ris. Tek. SIpil dan Arsit., vol. 16, no. 2, pp. 179-190, 2020.

[13] T. Hartadi and M. F. Ni, "Study on the Feasibility of Construction of Logung Dam in Kudus Regency," no. C, pp. 602-607, 2017.

[14] L. A. Rahman, S. Azis, and B. Wedyatadji, "Analysis of Investment Feasibility to Pedestrian Bridge in Muara Teweh - Jingah," Int. J. Sci. Technol. Res., vol. 6, no. 12, pp. 60-64, 2017.

[15] R. Respati, “Analisa Ekonomi Proyek Pada Pembangunan Palangka Raya Mall,” MEDIA Ilm. Tek. SIPIL, vol. 5, pp. 74-80, 2016.

[16] N. D. S. Adih Supriadi, La Ode Angga, Andi Taufan, Febrianty, Kurniawan Prambudi Utomo, Ajeng Septiana Wulansari, Ulfa Yuniati and N. K. R. Enok Nurhayati, Mira Rahmi \& Anggi Angga Resti, Lutfi, Studi Kelayakan Bisnis (Tinjauan, Teori dan Praktis). .

[17] P. Rejekiningrum and S. K. Saptomo, "Analisis Kelayakan Finansial Pengembangan Sistem Irigasi Cakram Otomatis Bertenaga Surya di Nusa Tenggara Barat," J. Irig., vol. 10, no. 2, p. 125, 2015.

[18] Samson and B. Priyambodo, "Kelayakan Ekonomi Pembangunan Infrastruktur Air Minum (studi Kasus Pembangunan SPAM Regional KOBEMA di Provinsi Bengkulu)," J. Sain dan Teknol. Tek. Utama, no. 3, pp. 1-28, 2020.

[19] M. Rifai and M. N. Sahid, "Studi Kelayakan Ekonomi Teknik Pembangunan Bendungan Randugunting," Pros. Semin. Nas. Tek. Sipil, pp. 225-238, 2019.

[20] Giatman, Ekonomi Teknik. PT Raja Grafindo Persada, 2006.

[21] D. Sinaga and H. Saragih, Studi Kelayakan Investasi pada Proyek dan Bisnis dalam Persfektif Iklim Investasi Perekonomian Global: Teori dan Aplikasinya dalam Menilai Investasi Modal dalam Proyek dan Bisnis. Jakarta: Mitra Wacana Media, 2013.

[22] Kuswadi, Analisis Perekonomian Proyek. Andi Offset, 2007. 